\title{
Estudo Exploratório: Ultra-Sonografia, Ecocardiografia Fetal e Resultados Perinatais em Gestantes Portadoras do HIV em Uso de Terapia Anti-Retroviral
}

Autor: Marco Antonio Borges Lopes

Orientador: Victor Bunduki

Tese de Doutorado desenvolvida na Clínica Obstétrica do Hospital das Clínicas da Universidade de São Paulo e apresentada na Faculdade de Medicina da Universidade de São Paulo, no dia 24/01/2003.

\section{Resumo}

Com o objetivo de descrever as alterações estruturais e/ou funcionais fetais à ultra-sonografia e ecocardiografia fetais, resultados perinatais e possíveis fatores de risco, foram avaliadas, retrospectivamente, com seguimento prospectivo, 109 gestantes soropositivas em uso de anti-retrovirais. Foram observados oito $(7,3 \%)$ casos de alterações estruturais fetais: quatro de cardiopatia congênita e quatro de nefropatia (hidronefrose). Noventa e cinco $(87,3 \%)$ dos RN foram considerados adequados para a idade gestacional, 11 $(10,0 \%)$, pequenos e $3(2,7 \%)$, grandes. A espessura e o peso placentários não estiveram alterados nas ges- tantes portadoras do HIV, sob terapia anti-retroviral. Foram diagnosticados oito $(7,3 \%)$ casos de oligoâmnio; onze $(10,0 \%)$ casos de polidrâmnio. A taxa de restrição do crescimento intra-uterino foi de $10 \%$, nessa população, sendo que o tabagismo e a carga viral foram os fatores de risco que apresentaram significância estatística para essa ocorrência. Apesar de a taxa de prematuridade $(8,7 \%)$ não ter sido exacerbada nessa série, a mortalidade foi alta $(5,5 \%)$ e o uso de terapia anti-retroviral (TARV), durante toda a gestação associou-se à incidência desse evento.

Palavras-chave: Pré-natal. Ecocardiografia. Diagnóstico pré-natal. 